\title{
Credit Risk Disclosure Compliance And Bank Performance In Nigeria: A Case Study Of Zenith Bank PLC
}

\author{
F. 0. Olaoye \\ Department of Accounting, \\ Faculty of Management Sciences, Ekiti State University \\ T. C. Ojuolape \\ Department of Accounting, \\ Faculty of Management Sciences, Ekiti State University
}

\begin{abstract}
The study examined the influence of credit risk disclosure compliance on bank performance in Nigeria. IFRS 7 state that entity should disclose credit risk in their financial report. Credit risk may affect going concern concept and audit report is silent about it. The specific objective of the study is to ascertain the influence of credit risk disclosure on bank profitability. Linear regression analysis was used to analyse the data collected from financial reports, with the help of SPSS 20.0 version. The study discovered that there is positive relationship between credit risk disclosure and bank profitability. The study therefore recommends that the financial institutions regulators should enforce credit risk disclosure in their financial reports as this will help the stakeholders to make informed investment decision.
\end{abstract}

Keywords: Credit Risk, Compliance, Bank Performance, Audit Report, Bank Disclosure and Audit Report

\section{INTRODUCTION}

According to Olweny and Shipho (2011) opines that banks are exposed to risks because of their roles of receiving deposit and advance loans to her customers. Many scholars agreed that bank intermediation roles induce their credit creation ability. Therefore, credit risk is one of the important hurdles that bedevil bank performance. Boahene et al. (2012) notes that credit quality is a vital indicator of sound and healthy banks.

Bank stakeholders are exposed to various types of risk and those risks are either fully disclosed or reported on by the auditors. International Financial Reporting Standards (IFRS) 7 (paragraph 33 - 42) states that "An entity shall disclose information that enables users of its financial statements to evaluate the nature and extent of risks arising from financial instruments to which the entity is exposed at the reporting date." Some of risks to be disclosed are: liquidity risk, market risk and credit risk.

The IFRS 7 states, in connection with credit risk, "banks should give information about the credit quality of financial assets that are neither past due nor impaired. The amount that best represents its maximum exposure to credit risk as at the reporting date. Banks are expected to comply with this rule. However, if all the attributes of credit risk are disclosed in financial report, will it affect the profitability of the bank? However, credit risk may affect going concern concept and audit report is silent about it. There have been various empirical studies on impact of risk management on banks profitability but the researcher is not aware of any empirical study on credit risk disclosure compliance and bank profitability in Nigeria. Hence, this study stands to fill the gap. 
The specific objective of the study is to ascertain the influence of credit risk disclosure compliance on bank profitability in Nigeria. The study will be guided by this hypothesis that, there is no significant relationship between credit risk disclosure compliance and bank profitability in Nigeria.

\section{Scope of the study}

The study will cover credit risk disclosure in financial report of Zenith Bank Nigeria plc. We shall focus on the Zenith bank in Nigeria and the whole Zenith group. We are going to cover the period of 2015 -2016. Zenith Bank Nigeria Plc was selected as a case study because it is one of the oldest banks in Nigeria.

\section{Conceptual review Credit risk disclosure}

Credit risk is when a customer that borrow money from the bank failed to meet its obligation according to the agreement, Basel Committee on Banking Supervision (2000). Chen and Pan (2012) define credit risk as the extent of value fluctuation of loans and derivatives due to change in the credit quality of borrowers and counterparts. According to Coyle (2000) it is the loss from inability or refusal of customer to pay what he is owed to pay.

Credit risk mainly arises due to lack of institutional capacity, in appropriation of credit policies, interest rate volatility, poor quality of management, lapses of laws and regulations, liquidity constraints and inappropriate credit assessment, inefficient lending practices and interference of government by central bank (kithinji, 2010). Credit risk arises any time bank funds are extended, committed, invested, or otherwise exposed through actual or implied contractual arrangements, whether reflected on or off the balance sheet (Kargi, 2014).

\section{Profitability}

Profitability is the earning power of a business entity. It is an important element of the bank's value creation and a critical step toward shareholders' wealth maximization. Previous studies have used ROA, computed by dividing the net income by the total assets of a bank, as the primary measure of bank profitability (Abbas et al., 2014; Akhtar et al., 2011; Gizaw et al., $2015\}$.

\section{Empirical review}

Mendoza and Rivera (2017) examine the credit risk and capital adequacy of the rural banks in the Philippines. The study found out that credit risk has a negative and statistically significant relationship with profitability. Credit risk has a significant negative influence on profitability Staikouras and Wood (2004). Likewise, Ali et al. (2011) and Flamini et al. (2009) derived the same results.

When Kolapo et al. (2012) used panel model analysis for five commercial banks in Nigeria, they concluded that credit risk has significant impact on ROA. Moreover, Gizaw et al. (2015) deduced that credit risk has significant impact on profitability when they studied 18 Ethiopian commercial banks. Aremu et al. (2013) resolved that credit risk is a significant driver that affected bank profitability both in the long run and the short run - an observation made when they used the co integration and Error Correction Mechanism (ECM) in the First Bank of Nigeria. 
There is little or no empirical studies on financial instrument disclosure on credit risk compliance in developing countries, especially in Nigeria. Hence, this study intends to fill the gap.

\section{METHODOLOGY}

Case study design was used for the study. The study uses secondary data collected from annual financial report published by Zenith Bank Nigeria Plc in2015 and 2016. Credit risk disclosure was measured with seven IFRS 7 disclosure items on credit risk in balance sheet.

Hodgdon et al. (2009) identified three procedures for scoring items in accounting research. These are the dichotomous method, the partial compliance method and the Saidin index method. The dichotomous method scored an item as "1" if disclose or" 0 " otherwise and there is no penalty for non-disclosure (Abdullah, 2013).The partial compliance computes the ratio of compliance by adding the extent of compliance for each standard and divide the sum by total number of standards applicable to the studied company (Abdullah, 2013). The Saidin index applies a weight sum to each IFRS with each weight measuring the ratio of companies, which claim to disclose (Spetz \& Baker, 1999).This paper uses the unweighted scoring method consistent with prior studies (Abdullah, 2013; Hodgdon et al. 2009). Bank profitability will be measured by return on capital employed.

Linear regression model was specified as follows:

$$
\mathrm{BPfr}=\mathrm{f}(\mathrm{Crdr})
$$

The hypothesis proposed for confirmation in this study is: there is no significant relationship between credit risk disclosure compliance and bank profitability in Nigeria.

$\mathrm{BPfr}=\beta 0+\beta \mathrm{i} \mathrm{Crdr}+$ eijk .eqi

$\beta 1>0$; R2Crpd $>0$

$\beta 1$... measure the effect of credit risk disclosure compliance and bank profitability.

Where:

BPfr $=$ Bank profitability

$\mathrm{Crdr}=$ credit risk disclosure compliance

$\mathrm{Ei}=$ Error term

$\beta 0$, and $\beta \mathrm{i}=$ Coefficient

\section{Test of hypothesis:}

\section{FINDINGS AND ANALYSIS}

Ho: there is no significant relationship between credit risk disclosure compliance and bank profitability in Nigeria

Table 1. The model summary

\begin{tabular}{|l|l|l|l|l|l|}
\hline \multirow{2}{*}{ Model } & \multicolumn{4}{|c|}{} & \\
\cline { 2 - 6 } & $\mathrm{R}$ & R Square & $\begin{array}{l}\text { Adjusted R } \\
\text { Square }\end{array}$ & $\begin{array}{l}\text { Std. Error of } \\
\text { the Estimate }\end{array}$ & Sig. F Change \\
\hline 1 & .919 & .845 & .814 & .00996 & $.003^{\mathrm{b}}$ \\
\hline
\end{tabular}

Predictors: (Constant), credit risk disclosure compliance

Dependent Variable: bank profitability

Source: Authors own study 2017. 
In the first table (1) entitled the model summary, the value of $\mathrm{R}$ value $=.919$; however $\mathrm{R}^{2}=$ .845 shows that $84.5 \%$ of the dependent variable (return on capital employed) has been explained by the independent variable; credit risk disclosure compliance.. However, the unexplained variation is 0.155 which is about $15.5 \%$; thus we can understand that the model is providing a good fit to the data since the unexplained variation is 0.155 .

Table 2. ANOVA and the significance of the model

\begin{tabular}{|c|c|c|c|c|c|c|}
\hline \multicolumn{7}{|c|}{ ANOVAb $^{b}$} \\
\hline \multicolumn{2}{|c|}{ Model } & Sum of & $\mathrm{df}$ & Mean & $\mathrm{F}$ & Sig. \\
\hline \multirow[t]{2}{*}{1} & Regression & .003 & 1 & .003 & 27.290 & $.003^{\mathrm{b}}$ \\
\hline & Residual & .000 & 4 & .000 & & \\
\hline
\end{tabular}

Source: Authors own study, 2017.

ANOVA results (specifically f-ratio) test the overall significance of the model. The $f$-ratio (27.290) shows that the variables, credit risk disclosure compliance, are the major determinants in explaining bank profitability. It can be observed that the independent variables give a significant effect on the dependent variable based on the $f$-ratio, suggesting that; overall, the model in the study is significantly good enough in explaining the variation on the dependent variable. The independent variables are statistically significant because its significance value is 0.003 , that is $P<0.05$. So the null hypothesis is rejected while alternative hypothesis is accepted. Therefore, there is significant relationship between credit risk disclosure compliance and bank profitability in Nigeria.

\section{DISCUSSION, CONCLUSION AND RECOMMENDATION}

It was discovered that Zenith Bank Plc complied with IFRS 7 credit risk disclosure in their annual financial report for 2015 and 2016. This have influence on their return on capital employed. However, some information about credit quality of financial assets are not clearly stated in the financial report.

From the above analysis, the study discovered a positive relationship between credit risk disclosure compliance in accordance with IFRS 7 and bank profitability. When the bank disclosed their credit risk information, many customers are reduce their business transaction with the business and it reduce their credit creation capacity.

The researcher recommends that the financial institutions regulators should enforce credit risk disclosure in their financial reports. This will help the stakeholders to make informed investment decision. Moreover, it reflect the true identity of the financial health of the bank. However, this study focus on only zenith Bank Nigeria Plc. Future researchers is encouraged to increase their scope to cover more banks in Nigeria.

\section{References}

Abbas, A., Haider, A. and Rana, U. A. ( 2014). Credit risk exposure and performance of banking sector of Pakistan. Journal of Basic and Applied Sciences, 4(3), 240-245.

Abdullah, M. (2013). Quality of corporate mandatory disclosure in Malaysia: evidence from two methods. 4th international conference on business and economic research (4th ICBER 2013) proceeding 04 - 05 March 2013. Golden Flower Hotel, Bandung, Indonesia. Website: www.internationalconference.com.my

Akhtar, M. F., Ali, K. and Sadaqat, S. (2011). Factors influencing the profitability of Islamic banks of Pakistan. International Research Journal of Finance and Economics, 66, 125-132. 
Aremu, M. A., Ekpo, I. C. and Mustapha, A. M. (2013). Determinants of banks' profitability in a developing economy: Evidence from Nigerian banking industry. Interdisciplinary Journal of Contemporary Research in Business, 4(9), 155-181.

Ali, K., Akhtar, M. F. and Ahmed, H. Z. (2011). Bank-specific and macroeconomic indicators of profitability: Empirical evidence from the commercial banks of Pakistan. International Journal of Business and Social Science, 2(6), 235-242.

Basel Committee on Banking Supervision (2000). Principles for the management of credit risk. 1-26. http://www.bis.org/publ/bcbs75.pdf.

Boahene, S. H., Dasah, J., and Agyei, S. K. (2012). Credit risk and profitability of selected banks in Ghana. Research Journal of Finance and Accounting, 3(7), 6-14.

Chen, K. and Pan, C. (2012). “An Empirical Study of Credit Risk Efficiency of Banking Industry in Taiwan”, Journal of Chinese Management Review, 15(1), 1-16.

Coyle, B. (2000). “Framework for Credit Risk Management”, Chartered Institute of Bankers, United Kingdom

Flamini, V., McDonald, C. and Schumacher, L.(2009). The determinants of commercial bank profitability in SubSaharan Africa IMF Working Paper, 1-30.

Funso, K.T., Kolade. A.,R. and Ojo, O.M.(2012).“Credit risk and commercial banks performance in Nigeria: A model approach, Australian Journal of Business and Management Research,2(2), 31-38.

Kithinji, A.M. (2010). "Credit Risk Management and Profitability of Commercial Banks in Kenya”, School of Business, University of Nairobi.

Gizaw, M., Kabede, M. and Selvaraj, S. (2015).. The impact of credit risk on profitability performance of commercial banks in Ethiopia. African Journal of Business Management, 9(2), 59-66. doi: http://dx.doi.org/10.5897/AJBM2013.7171

Hodgdon, C., Tondkar, R. H., Adhikari, A. and Harless, D. W. (2009). Compliance with international financial reporting standards and auditor choice: new evidence on the importance of the statutory audit. The International Journal of Accounting, 44, 33-55.

International Accounting Standards Board. (2007). International financial reporting standards, IFRS7 Financial Instruments: Disclosures. London: IASB.

Kolapo, T. F., Ayeni, R., Kolade, O. and Ojo, M.,(2012).. Credit risk and commercial banks' performance in Nigeria: A panel model approach. Australian Journal of Business and Management Research, 2(2), 31-38.

Olweny, T. and Shipho, T. M.(2011).. Effects of banking sectoral factors on the profitability of commercial banks in Kenya. Economics and Finance Review, 1(5), 1-30.

Spetz, J. and Baker, L. (1999). Has managed care affected the availability of medical technology? Public Policy Institute of California, Baker, San Francisco, CA.

Staikouras, C. K. and Wood, G. E. (2004). The determinants of European bank profitability. International Business and Economics Research Journal, 3(6), 57-68. 